\title{
Cofán Indians' monitoring of freshwater turtles in Zábalo, Ecuador
}

\author{
WENDY R. TOWNSEND ${ }^{1, *}$, RANDALL BORMAN A. ${ }^{2}$, \\ EDUARDO YIYOGUAJE ${ }^{2}$ and LUIS MENDUA ${ }^{2}$ \\ ${ }^{1}$ The Field Museum, Chicago, Ill, Casilla 6266, Santa Cruz, Bolivia; ${ }^{2}$ Cofán Survival Fund, Domingo \\ Refingo, Quito, Ecuador; *Author for correspondence (e-mail: wtownsend@fieldmuseum.org; fax: \\ $+591-3-355-6925)$
}

Received 2 April 2004; accepted in revised form 18 October 2004

Key words: Amazon river turtles, Cofán, Community-based monitoring, Ecuador, Freshwater resources, Locally-based monitoring, Podocnemis expansa, Podocnemis unifilis, Zábalo River

\begin{abstract}
The Cofán Indians of Aguarico and Zábalo Rivers in Ecuador in 1990 began a turtle recuperation effort by raising turtle hatchlings (Podocnemis expansa and P. unifilis) in small pools. To evaluate the effectiveness of this program, the Cofán developed and tested three methods to document changes in the populations of turtles. The first method consisted of interviews with people from neighbouring communities about their perceptions of changes in turtle abundance. The second method was a direct count of turtles observed along the rivers from canoe. The third method was an indirect count, involving turtle nest censusing along community beaches. Two of the methods yielded numerical, statistically positive turtle population trends. The turtle program has influenced the community's perception of turtle conservation issues so that, instead of hunting the adults and eggs, they now protect them. The training in record-keeping permits them to make a transparent history of the equitability of access to the turtle egg resource. The Cofán monitoring experience strengthened their successful petition to the Ecuadorian government for the rights to manage their territorial lands within the Cuyabeno Wildlife Reserve, and to receive protected area status and management rights to other ancestral lands. The experience gained by the Zábalo monitors is now serving as a model for the design and implementation of the park monitoring system of the newly-established Cofán Park Ranger Corps, which will be patrolling three Ecuadorian Ecological Reserves which overlap Cofán inhabited areas.
\end{abstract}

\section{Introduction}

Early explorers of the Amazon were astounded by the large populations of Amazon river turtles, (Podocnemis expansa and P. unifilis), and often described their pleasure at consuming the meat and eggs of these species (Medina 1934; Smith 1974). These turtles also served as food reserves for riverine peoples such as the Cofán of the Aguarico River Basin of eastern Ecuador. The turtles were captured alive and kept in corrals; and the eggs, an important source of fats in an extremely low fat diet, were salted, dried, and used throughout the year.

Populations of these two species have declined dramatically over all of their range, with the larger of the two, $P$. expansa, now close to extinction in the Aguarico River (Velasco 1994), and the smaller P. unifilis declared vulnerable by the IUCN (2003). Population declines stem from over-hunting of adults and 
eggs, an activity that accelerated with the influx of petroleum workers from other parts of Ecuador to the Aguarico River basin. By the time the Cofán village of Zábalo was established on the lower Aguarico River in 1979, neither species of turtle was common. Shortly thereafter, the community began to control turtle harvesting activities by its own initiative after suggestions from conservation minded tourists and scientists. It was not until 1990 that, together with a local conservation organization, they began a proactive program directed at the recuperation of the populations of river turtles. The Cofán began with population monitoring, beach protection, and raising hatchlings in small pools, a process called 'head-starting' (Acosta 1996).

The decline of freshwater turtles and other threatened species of wildlife in Amazonia is difficult and costly to assess when research is limited to expedition-led monitoring because most remaining populations are far from academic centers. Monitoring by scientists can fail to include training of local people or leave appropriate infrastructure behind so that the locals can continue the monitoring (Danielsen et al. 2003). In the scientific literature there are few examples of environmental monitoring systems implemented by indigenous communities (but see, Noss et al. 2005 (this issue)). While volunteer-based monitoring of freshwater resources are undertaken in several northern countries (e.g., Bray and Schramm 2001; Fore et al. 2001), there are relatively few documented examples of community-based monitoring of freshwater habitats and wildlife populations from developing countries (see Andrianandrasana et al. 2005 (this issue) for an example from Lac Alaotra, Madagascar). This paper examines the freshwater turtle monitoring system of the Cofán and discusses the benefits from this monitoring activity for the Cofán and for the populations of river turtles.

\section{Description of Zábalo environment}

The Cofán village of Zábalo was established at an elevation of about $250 \mathrm{msl}$, on the banks of the Aguarico River, which is one of the main white water Amazon tributaries draining the eastern Ecuadorian Andes (Figure 1; Sioli 1984; Prance 1978; Pires and Prance 1985). The surrounding vegetation includes both inundated and non-inundated tropical forest, with a dominance of trees from the following families: Arecaceae, Mimosaceae, Moraceae, Caesalpiniaceae, Lauracea, Myristicaceae; in their turn, lianas are represented in particular by the Araceae, Loranthaceae and Polypodiaceae families (Cerón 1995). The upland forests grow predominantly along the ridges parallel to the Aguarico behind the community. The village takes its name from the Zábalo River, a black-water river system (Sioli 1984) that enters the Aguarico River about $1 \mathrm{~km}$ downstream from the community.

The aquatic environment of the Amazon river turtle is one of substantial seasonal change. During the rainy season, the rivers overflow into the forest, and the turtles disperse under the trees to compete with the large fish such as 


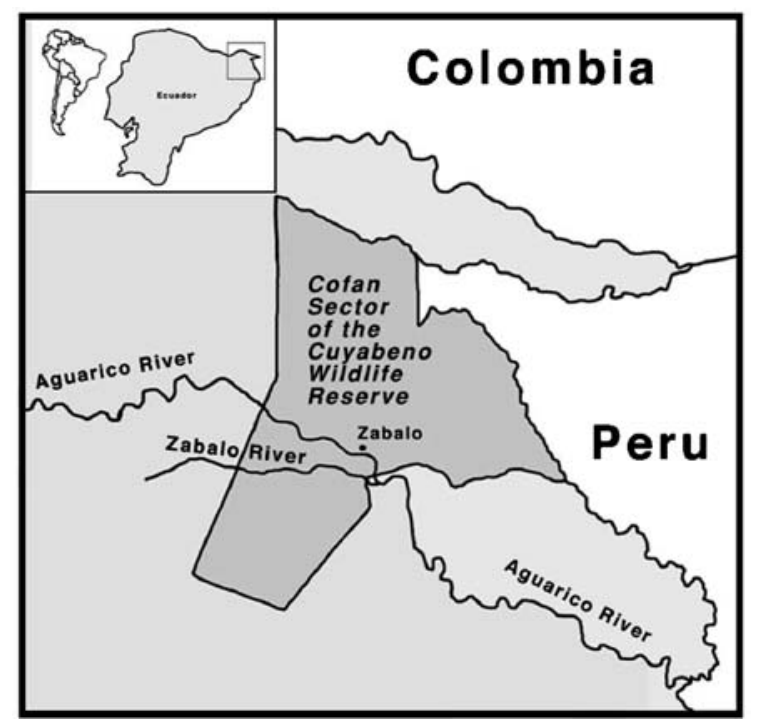

Figure 1. Location of freshwater turtle census areas in the Cofán sector of the Cuyabeno Wildlife Reserve, Zábalo, Ecuador.

Colossoma sp., Myleus sp., Mylosommasp., Triportheus sp. and Brycon sp. for the forest fruits, such as Mauritia flexuosa (Goulding 1985). When the dry season arrives, the swamps and oxbow lakes begin to dry by as much as 6-8 m (deVries et al. 1995), and the turtles return to the major watercourses to lay their eggs on the newly exposed white water-beaches.

\section{History of the Cofán people}

The Cofán culture probably has its roots in proto-Chibchan hunters who wandered down from the Colombian highlands near the present border of Colombia and Ecuador (Borman 2001). The Cofán were warriors, but they were also traders, embarking on long and dangerous voyages down to the Amazon River and back up its tributaries in search of cloth, salt, and sea shell beads. They resisted the Spanish settlers with a ferocity that culminated in the burning of the town of Mocoa and the siege of Pasto in what is now southern Colombia. Every campaign aimed at subduing the Cofán ended in defeat until 1602, when a Jesuit priest, Rafael Ferrer, made peaceful contact with the Aguarico Cofán (Gonzalez 1982).

In more recent times, the Cofán have witnessed the effects of poor environmental protection controls by oil companies and have fought to remain free from contamination by oil extraction activities. To this day, no damages have been paid for the pollution from two oil wells that operated within the Cofán territory until the Cofán forced the oil companies to abandon them. The Cofán 
have also watched the influx of settlers into their territory, with subsequent forest destruction, wildlife over-hunting, poisoning of streams, and other negative consequences. Extensive agricultural activities have turned a once productive forest into a landscape of poor farms, with only scraps of forest remaining outside the limits of Cofán territories. Satellite imagery of the area shows that the Dureno Cofán territory is the only native forest left for kilometers around (Pitman et al. 2002).

At present, the Cofán people are represented by seven communities in Ecuador, with a total of about 1000 people. In addition, an unknown number live in Colombia, where there are at least four culturally intact communities and several other groups in various states of acculturation. In Ecuador, the Cofán generally understand rudimentary Spanish, although the majority cannot express themselves comfortably in that language. Education is state-run and available in the communities until about third or fourth grade, but the Fundación Sobrevivencia Cofán has arranged high school opportunities for some Cofán students in Quito, and one student is completing high school in the USA. Education is considered an important survival strategy for the Cofán.

In the face of the negative environmental impacts during the late 1970's and early 1980's, Cofán from many communities, with a predominance of people from Dureno, decided to move farther down the Aguarico River to a traditional summering ground. The new community became known as Zábalo $\left(0^{\circ} 21^{\prime} \mathrm{N}\right.$ and $\left.75^{\circ} 40^{\prime} \mathrm{W}\right)$. There the Cofán people subsist by gardening, producing plantains, bananas, and manioc, and supplementing their diet by hunting and fishing. Cash is earned through guiding tourists, folk crafts sales, and wage labour.

\section{Freshwater turtle management}

By the time Zábalo was established, the river had already been affected by oil exploitation, and the turtle populations had been reduced by commercial egg harvesting. Since the 1970's, when the Cofán formed their own tourism business, their contact with conservationists has stimulated local awareness of these issues. Cofán concern for the diminishing turtle population moved them to ban hunting of adult turtles, in the hope that population trends would reverse and they could once again use the resource. During the 1980's the Cofán joined a collaborative effort for turtle management with local NGO's and in 1990, the Cofán formed a research alliance with an Ecuadorian university (La Catolica), and with the Fundación Herpetológica Gustavo Orces operators of the Vivarium of Quito. Their early evaluations suggested there remained only a small nesting populations of $P$. unifilis and almost no P. expansa (Velasco 1994, 1995) in the area of Zábalo.

As a result of this collaboration, a complete ban on the hunting of adult turtles was established by community initiative. A reduction of the egg harvest was stimulated by monetary incentives to produce hatchlings ( $\$ 0.25$ each) 
destined for a community 'head-starting' program. This program provides for the purchase of hatchlings that are maintained in pools for a year. By this time they are large enough to escape from most predators (Acosta 1996). It soon became important to the Cofán to evaluate the results of the 'head-starting' program. In 1998, The Field Museum of Chicago formed a partnership with the Cofán as a part of its Environmental and Conservation Programs, and provided technical guidance to facilitate the development, together with Cofán, of a systematic method of monitoring the turtle population. From that year forward, the Cofán have recorded all nests on the community-controlled beaches. In 1999, a visual turtle census was initiated with five Cofán monitors recording turtle sightings along the parts of the Aguarico and Zábalo rivers under Cofán control.

\section{Freshwater turtle monitoring methods}

The Cofán were enthusiastic assistants for the early studies by Velasco (1994, 1995). They began their own experiments with growing turtle hatchlings in old canoes. The new partnership with The Field Museum promoted greater participation in the research by the Cofán and provided scientific advice on design and analysis, as well as funding allowances for Cofán monitors ( $\$ 100$ / month) and coordinators (\$150/month), and the economic incentives for the hatchling program. Cofán monitors and coordinators collect the data, are taught to enter data into computers, participate in the analysis and design of their programs, and present the results to the community for decisions affecting the turtle harvest.

The objective of the monitoring is to assess the size of the turtle population and to document population trends that could result from Cofán turtle conservation efforts. To this end, the Cofán experimented with three methods: interviews with local people from other communities, a turtle census along the river; and an indirect method to assess the turtle population by counting turtle nests on the community controlled beaches. The indirect method is based on the fact that each adult female lays only one clutch per year (Hildebrand et al. 1988). Each of these methods is described briefly below and in Table 1.

The first method involved 20 interviews with neighbouring colonists and other indigenous people undertaken by a professional anthropologist and two Cofán coordinators. These interviews were based on a semi-structured interview guide and focused on documenting perceptions about recent river turtle population trends.

The second method comprised turtle visual census which was undertaken every 10-14 days by five Cofán monitors paddling in small canoes from which they counted the number of turtles they observed. On sunny days the river turtles, mostly P. unifilis, haul themselves out of the water to bask on overhanging tree branches. Monitors count them in three size categories and also 


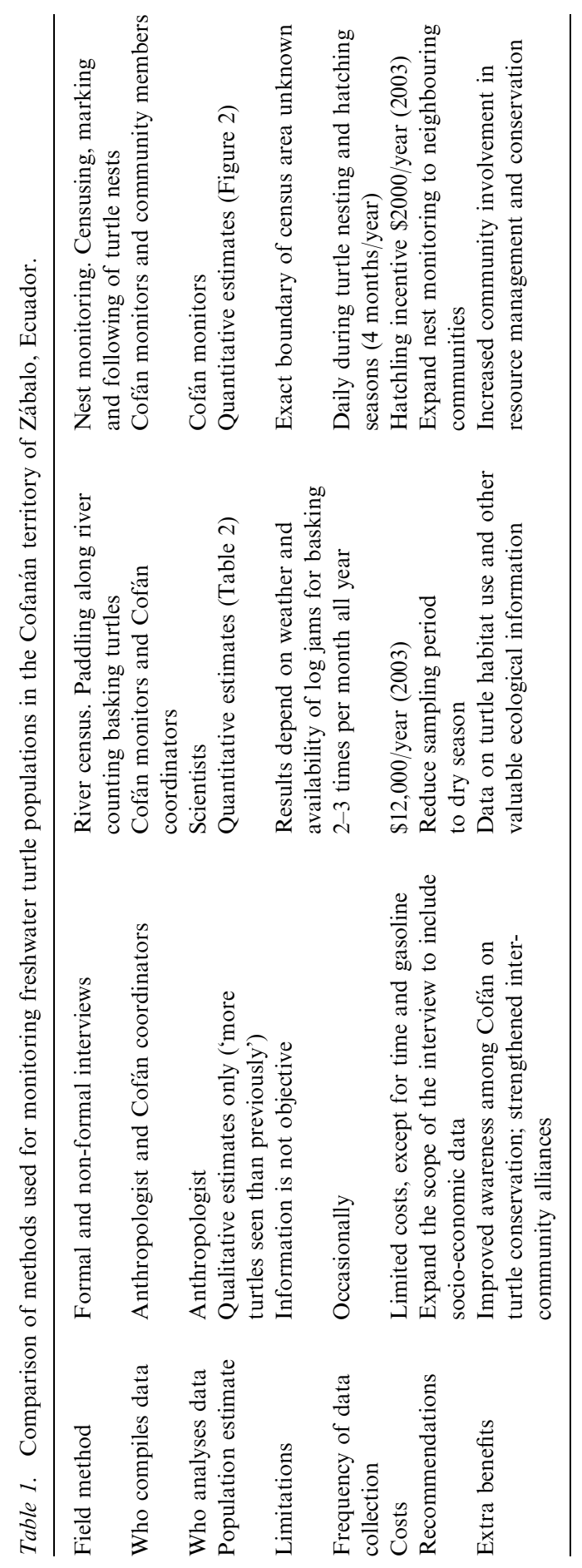


report on the relative height of the river. The information is entered on Excel spreadsheets and basic analysis is performed using Excel version XP. Since these repeated efforts are 'true' counts over a known area (the turtles do not live away from the water), we can consider the maximum counts as being minimum estimates of the turtles in the river.

The third method, counting the number of turtle nests on the community beaches, was an indirect tool for recording change in the turtle population. By carefully searching the nesting beaches, community members identify $P$. unifilis nests, which are marked and credited to the finder. These nests are followed until hatching occurs, whereby the finder receives a small compensation for each hatchling $(\$ 0.25)$. These young turtles are then transferred to pools where they are fed the entire year, and then released into local oxbow lakes. In recent years, as the number of nests has increased, some nests have been harvested by community members for consumption. This decision is freely made, but the user forgoes the economic incentive of selling the hatchlings to the program. During a community meeting, Cofán families are assigned specific days to search for nests on specific beaches. If they find a nest, they can choose whether to harvest the eggs or protect them for the hatchlings and receive the economic incentive. The nest searcher may also decide to harvest the eggs instead of risking their loss from flooding. The number of nests harvested, the number of eggs in each nest, and the beach where they were found are all reported by the nest finder to the monitors. The Cofán coordinator gathers the information from the different monitors into a single report which is analyzed with M.S. Excel. The hatchling incentives are distributed by the coordinators.

Six monitors and two coordinators are presently paid through donations from conservation foundations. In the beginning, the project cost as little as $\$ 2000$ per year to operate; currently, the paid monitors raise expenses to about $\$ 12,000$. In addition, The Field Museum has purchased computers and membrane liners for turtle pools. The full-time monitoring costs could not be met without external economic inputs. The monitors presently census 10 days per month and coordinators tend turtle hatchlings daily. During the turtle nesting season from October-March, beach monitoring and protection tasks increase the monitors' and coordinators' time commitment at least two-fold.

\section{Results}

The results of all three community-based monitoring methods suggest that the populations of freshwater turtle $P$. unifilis are increasing in the Zábalo area. The methods varied from each other with respect to their usefulness and to the type of data they generated (Table 1).

The least effective method for evaluating the freshwater turtle population was the interviews of neighbours about their perception of population trends. Although the interviewers received prior training and practice in interviewing skills, and interviews were done with the support of a professional 
anthropologist, interviewees had difficulty answering the questions about the turtle population trends. The method was abandoned after 20 interviews because it was also costly in terms of time and gasoline. The main benefit of this method was the basic communication skills obtained by the Cofán coordinators from the anthropologist's training. The coordinators also had the opportunity to share their experiences in turtle conservation with others with their newly learned Spanish terminology. However, they were generally uncomfortable with the task, being insecure about their Spanish language skills. Although the interview method proved imprecise as a population monitoring tool, experiences from other areas (e.g., van Rijsoort and Jinfeng 2005 (this issue)) suggest that this method can yield useful information on perceived population trends of wildlife. The immediate benefit of the interviewing effort in Zábalo was a strengthened alliance with two neighbouring communities which led to extension of the freshwater turtle recuperation programme to their areas of the rivers.

The river census provided numerical data on turtle population which indicate a significant increase in the numbers of $P$. unifilis in the Zábalo area (Pearsons' correlation, $p<0.05$; Table 2). Since these figures are maximum counts for the $28 \mathrm{~km}$ of the Aguarico River and about $20 \mathrm{~km}$ of the Zábalo River, the highest numbers each year or month could be considered as a minimum figure for the turtle population. This field method is straightforward for the Cofán to use, but the data were difficult to interpret because the figures varied substantially from month to month. The Cofán monitors gained considerable experience from the turtle river censuses. The variations in numbers have stimulated discussions about adjusting the census periodicity to focus only on the dry season when more sunning logs are exposed, and turtle sunning

Table 2. Number of Amazon river turtles (Podocnemis expansa and P. unifilis) sighted during the Cofán Indians' turtle monitoring of the Aguarico and Zábalo rivers, Ecuador, January 1999-April 2003.

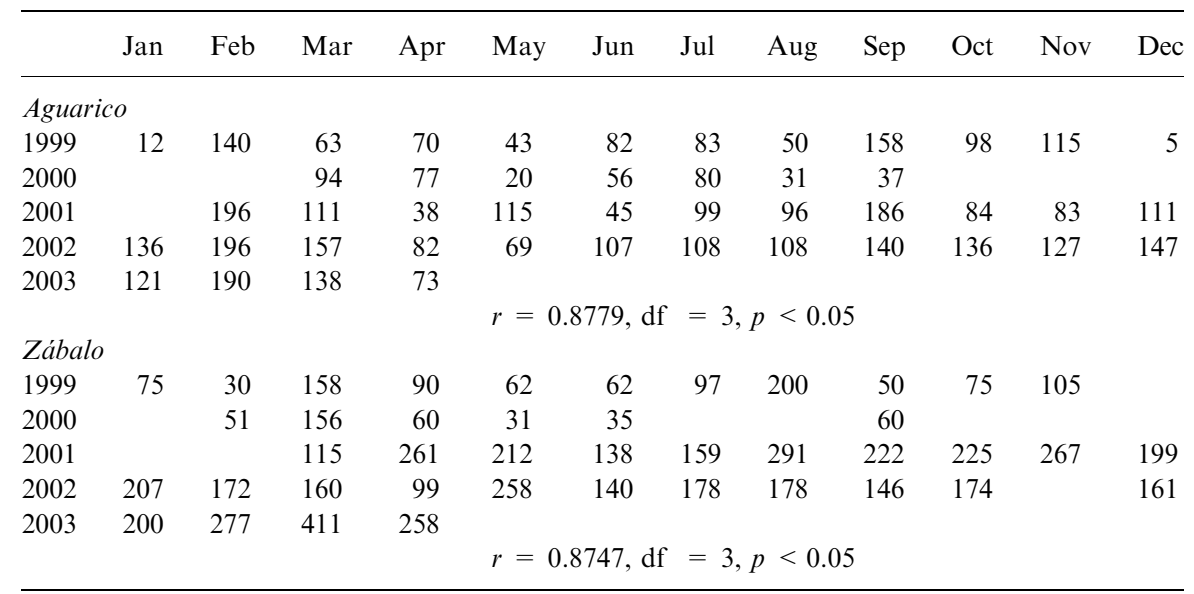


behaviour is at its maximum prior to egg laying (Hildebrand et al. 1988). Monitoring costs could then be reduced while the method could still provide other social benefits like patrolling the rivers for turtle poachers and potential intruders to the territory of the Cofán. Territorial protection is particularly important during the turtle nesting season to keep outsiders from pilfering the marked nests on the beaches.

The river census of turtles fits into what the Cofán like to do and do well: navigate rivers and find the best turtle sunning areas. This local experience and ability to paddle small canoes increased the efficiency of the monitors in systematically recording turtle sightings into notebooks.

The third monitoring method provided data on the number of turtle nests on the communal beaches. The findings from this method suggested a significant increase in the nesting population of $P$. unifilis on the Zábalo beaches (Pearson Correlation: $r=0.94011$, df $=3, p<0.05$ ), Figure 2. This method requires full-time attention for half of the year, during the turtle nesting season from late October until early March. The method is culturally relevant to the Cofán because they traditionally searched for turtle eggs as a food source. The method encourages participation of all segments of the Zábalo community because the hatchling incentives are distributed to all the Cofán families involved. For the participants in the nest identification and hatchling registry, turtles have taken on an important new economic value from which they benefit directly. By identifying the nests on their beaches, the Cofán get a fairly direct understanding of the turtle population trends and can adapt the management and adjust their harvesting behaviour accordingly. In parallel with monitoring the fate of the nests, the Cofán have rescued 100 of eggs that would have normally been lost to flooding. This experience suggests a change in Cofán awareness of conservation; prior to the establishment of the turtle program, finding but not collecting eggs would never have been considered.

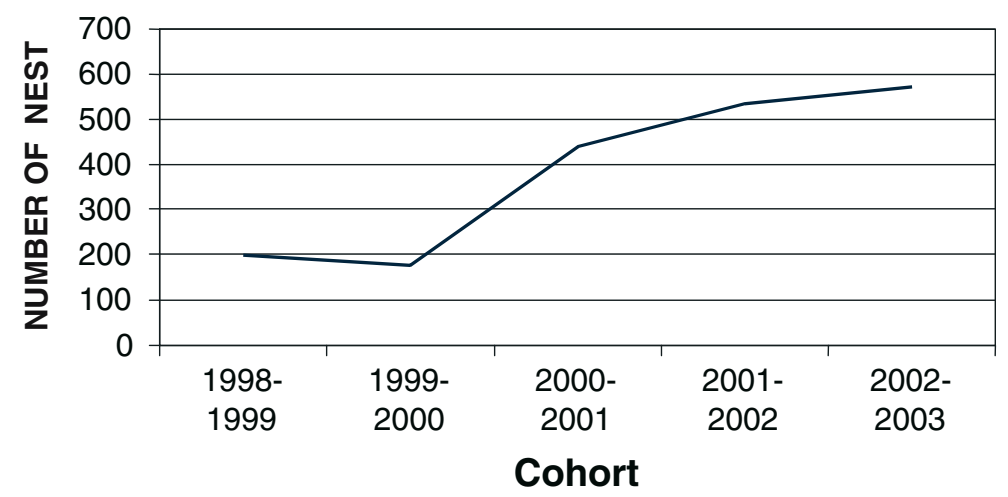

Figure 2. Number of nests of Amazon river turtle Podocnemis unifilis on the communal beaches of Zábalo, Aguarico River, Ecuador, 1998-2003, based on counts made by the Cofán Indians. 
However, the real test of this will come when the conservation incentives are stopped.

\section{Discussion}

In the 1980s, the Cofán joined with national and international academic institutions and conservation organizations who are vocal stakeholders in freshwater turtle conservation. As a result of this alliance they began the present turtle recuperation effort. The increase in the local nesting population of the vulnerable species $P$. unifilis may reflect female migration into the area, especially since the beaches of the Cofán Territory of Zábalo are now protected and thus left undisturbed during the nesting season. On the other hand, the rapid increase in number of nests that occurred from 1999 to 2000 (see Figure 2) was made up of small clutches (unpublished data), suggesting that the eggs were laid by young females (Hildebrand et al. 1988). The increase in the population may therefore be a direct result of the head-starting activities initiated 7 years earlier (Velasco 1994, 1995), especially since it coincides with the age of sexual maturation for the species.

Aside from important census results achieved through the Cofán monitoring efforts, the program also raised awareness of freshwater turtle conservation issues among the Zábalo community. A complete ban on the killing of adult turtles has been introduced, and access to eggs is now controlled. The ban has been effective for over 10 years so that a generation of Cofán children do not now consider turtle meat edible. Nest counting has permitted a mechanism for equitably dividing access to the limited resource of turtle eggs. Because this system is culturally relevant, it is becoming an accepted community responsibility, with sanctions and fines applied to those who do not comply with the turtle bans and egg hunting schedules. Nests have only been harvested after their numbers began to increase in 2001. The financial incentive for producing hatchlings may be a factor in the recuperation of the nesting populations. We therefore suggest that this very low cost (\$2000/year) incentive system be supported by conservation organizations until the freshwater turtle populations have further recuperated.

Training in specific observation techniques such as the proper use of binoculars has helped monitors improve their accuracy in reporting and distance estimating. It is to be expected that the precision of the turtle counts will increase with the improved observation skills. The Cofán have learned skills that have allowed them to prove their abilities before the Ecuadorean Environmental Ministry and obtain management rights over their territories when these overlap with ecological reserves. Along with the responsibility of management of their territories comes the implementation of a Cofán Park Ranger program that is following examples and experiences from the Zábalo freshwater turtle monitoring system in the design of a coordinated monitoring system for the three protected areas under Cofán management. The park 
ranger monitoring program uses simple, low cost techniques with minimum equipment and a schedule that can be locally implemented without having to wait for an outside expert to oversee the project. The Cofán Park Rangers will eventually be responsible for the freshwater turtle monitoring, especially if outside funding for a specific turtle project becomes a limitation.

The Cofán have proven to be capable environmental monitors. By recording their observations in a rigorous manner, they obtained useful estimates of the turtle population and reproduction in the Zábalo area. An academic monitoring team might obtain a more precise population estimate, but Cofán monitoring was able to cover more area and more seasons. For the price of five years of Cofán monitoring $(\$ 60,000)$, perhaps one academic expedition could have taken place to undertake a one-time assessment. The Cofán contribution to the scientific knowledge of $P$. unifilis is already substantial (Mendua et al. 2004; Yiyoguaje et al. 2004). There is still considerable research needed for efficient management of these vulnerable freshwater turtles. It is necessary to understand survival and migration rates as well as other ecological questions on diet and reproduction. Most future research questions on Amazonian river turtles will require more sophisticated tracking equipment, but the Cofán are willing to expand their experience.

The overall incentive for the Cofán to develop and engage in these various conservation measures is complex and stems mainly from their experience with oil contamination in their communities, encroaching colonization of their territories, and an overall degradation of the forests of the Aguarico River Basin. Since 1964, when the oil companies began their operations, the Cofán have seen graphic examples of what western development has to offer. In contrast, conservation oriented activities ranging from the turtle project to tourism proved to be more compatible with the survival of the Cofan culture. Moreover, the community members are seeing how the results of their monitoring program can support the local knowledge in contamination disputes. Years of struggling against oil polluters have shown them how the environmental changes must be documented to be useful in legal demands. Learning to monitor their environment is a useful tool to substantiate future Cofán claims against environmental degradation. The two successful monitoring methods help calibrate and translate local perceptions of change into what an experienced biologist can understand and interpret to the courts.

The turtle monitoring system thereby offers more than just numerical population estimates, it provides - what is probably much more important from a conservation perspective - a way for the entire community to integrate into conservation efforts.

\section{Acknowledgements}

This paper is an expanded version of a presentation we were invited to make at a symposium on locally-based monitoring in Denmark in April 2004 
(www.monitoringmatters.org). The symposium was organized by the Nordic Agency for Development and Ecology (NORDECO, Denmark), and the Zoology Department of Cambridge University (UK). The authors would like to thank A. M. Velasco for pioneering the Aguarico turtle work and the Zábalo monitors for their diligence: C. M. Yiyoguaje, A. Yiyoguaje, A. Aguinda, B. Criollo, A. Lucitante, A. Lucitante, B. Machoa, and R. Criollo. In addition, we would like to thank the anthropologist who guided the interviews, M. L. Cepek. We would also like to thank the community of Zábalo for their participation in the turtle project as part of their interest in the conservation of their natural resources and the management of their territory. Our gratitude is also for A. M. Paredes who entered the data and E. Topp-Jørgensen who's statistical help was invaluable. We owe our thanks also to F. Danielsen, M. Funder, A. Stearman, and the anonymous reviewers for their insightful guidance. The Gordon and Betty Moore Foundation has funded The Field Museum work with the Cofán.

\section{References}

Acosta J. 1996. Protección y manejo de la tortuga charapa en la amazonia ecuatoriana: el caso de la Reserva de Producción Faunistica Cuyabeno. In: Campos Rozo C., Ulloa A. and Rubio Torgler H. (eds), Manejo de fauna con comunidades rurales. Fundación Natura, Santa Fe de Bogotá, Bogotá, Colombia, pp. 119-131.

Andrianandrasana H.T., Randriamahefasoa J., Durbin J., Lewis R.E. and Ratsimbazafy J.H. 2005. Participatory ecological monitoring of the Alaotra wetland in Madagascar. Biodivers. Conserv. 14: 2757-2774.

Borman R. 2001. History of the Cofán people. www /cofan.org

Bray G.S. and Schramm H.L.Jr. 2001. Evaluation of a statewide volunteer angler diary program for use as a fishery assessment tool. N. Am. J. Fisheries Manage. 21: 606-615.

Cerón C.E. 1995. Ethnobiologia de los Cofanes de Dureno. Publicaciones del Museo Ecuatoreano de Ciencias Naturales Serie: Monógrafia Año 10: 3. Herbario Nacional, Quito, Ecuador.

Danielsen F., Mendoza M.M., Alviola P., Balete D.S., Enghoff M., Poulsen M.K. and Jensen A.E. 2003. Biodiversity monitoring in developing countries: what are we trying to achieve? Oryx 37 : 407-409.

DeVries T., Campos F., De la Torre S., Asanza E., Sosa A.C. and Rodríguez F. 1995. Investigación y conservación en la reserva de producción funística Cuyabeno. In: Mena P. and Suarez L. (eds), Investigación para la conservación de la diversidad biológica del Ecuador: Memorias del simposio llevado a cabo del 10 al 12 de Junio de 1992. Quito, Ecuador, pp. 167-221.

Fore L.S., Paulsen K. and O'Laughlin K. 2001. Assessing the performance of volunteers in monitoring streams. Freshwater Biol. 46: 109-123.

Gonzalez J.R. 1982. La región amazonica del Ecuador en el siglo XVI. Banco Central del Ecuador, Editorial Graficos San Pablo,Quito, Ecuador.

Goulding M. 1985. Forest fishes of the Amazon. In: Prance G.T. and Lovejoy T.E. (eds), Key Environments: Amazonia. IUCN and Pergamon Press, New York, USA, pp. 267-277.

Hildebrand P., Saenz C., Peñuela M.C. and Caro C. 1988. Biología y conservación de la tortuga charapa Podocnemis expansa en el Río Caqueta en Amazonas, Colombia. Fundación Puerto Rastrojo, Bogotá, Colombia.

IUCN. 2003. IUCN Red List of Threatened Species. www.redlist.org

Medina J. 1934. The discovery of the Amazon according to the account of Friar Caspar de Carvajal (Oveido's version). In: Heaton H.C. (ed.), American Geographical Society Special Publication 17. Washington DC, USA. 
Mendua L., Yiyoguaje E., Borman R. and Townsend W.R. 2004. El programa de adelantamiento "head-starting" de neonatos de Charapa (Podocnemis unifilis) de la comunidad Cofán de Zábalo, Ecuador. In: VI Congreso sobre manejo de fauna silvestre en la amazonia y Latinoamérica 5-10 September 2004. Iquitos, Peru.

Noss A.J., Oetting I. and Cuéllar R.L. 2005. Hunter self-monitoring by the Isoseño-Guaraní in the Bolivian Chaco. Biodivers. Conserv. 14: 2679-2693.

Pires J.M. and Prance G. 1985. The vegetation types of the Brazilian Amazon. In: Prance G.T. and Lovejoy T.E. (eds), Key Environments: Amazonia. IUCN and Pergamon Press, New York, USA, pp. 109-145.

Pitman N., Moskovits D.K., Alverson W.S. and Borman R. 2002. Ecuador: Serranías CofánBermejo, Sinangöe. Rapid Biological Inventory No. 3. The Field Museum, Chicago, USA.

Prance G.T. 1978. The origin and evolution of Amazonian flora. Interciencia 3: 207-222.

van Rijsoort J. and Jinfeng Z. 2005. Participatory resource monitoring as a means for promoting social change in Yunnan, P.R. China. Biodivers. Conserv. 14: 2543-2573.

Sioli H. (ed.) 1984. The Amazon: Limnology and Landscape Ecology of a Mighty Tropical River and its Basin. W. Junk Publishers, Dordrecht, The Netherlands.

Smith N.J.H. 1974. Destructive Exploitation of the South American River Turtle. Yearbook of the Association of Pacific Coast Geographers, Vol. 36. Oregon State University Press, Ogden, USA.

Velasco A.M. 1994. Protección de la tortuga charapa en la Amazonia Ecuatoriana: Informe Final del proyecto de estudio. Fundación Hertetologica Gustavo Orces, Quito, Ecuador.

Velasco A.M. 1995. Protección de la tortuga Charapa en la Amazonia Ecuatoriana: II Fase. Pontifica Universidad Católica del Ecuador, Quito, Ecuador.

Yiyoguaje E., Mendua L., Borman R. and Townsend W.R. 2004. La tasa de eclosión de la Charapa (Podocnemis unifilis) del río Aguarico, Zábalo, Ecuador. In: VI Congreso sobre manejo de fauna silvestre en la amazonia y Latinoamérica. 5-10 Sept. 2004. Iquitos, Peru. 